\title{
Features of regenerative processes in case of extreme factors influencing the body
}

\author{
Sergey Tsvirenko*, Leo nid Saveliev, and Sergey Sazonov \\ Ural State Medical University, 620028, Repina st., bld.3, Yekaterinburg, Russia
}

\begin{abstract}
Changes in the specific liver mass, number of single and binucleate cells of different ploidy, mitotic index and alteration index, DNA content and inclusion of ${ }^{3} \mathrm{H}$-thymidine in DNA of Wistar rats and CBA mice in the following conditions: at $0^{\circ} \mathrm{C}$ for $3,7,14$ days for 23 hours per day, and in the highlands conditions $(3,200 \mathrm{~m}$ above sea level) for 3 and 30 days. Activation of regenerative processes has been established - proliferation of hepatocytes (mainly diploid) in combination with polyploid cell share reduction, as well as cellular hypertrophy development. Cell dynamics shifts persisted throughout the observation duration and were opposite in direction when growing up and aging.
\end{abstract}

\section{Introduction}

Body effects of various adverse and especially extreme factors are usually associated with tissue changes perceived to be directly or indirectly related to the functional system aging process and the limitation of its resource. However, it is undeniable that the action of external factors triggers multicomplex adaptation mechanisms; sustainable adaptation is impossible without the structural adaptation footprint, the formation of which is provided by regenerative processes in the modern understanding of their essence. The notion of the inextricable relationship of regeneration and adaptation became classic $[1,2]$. However, the effect of extreme factors on the regenerative processes themselves and the mechanisms of such influence are not fully studied [3-6]. Meanwhile, it is the state of regenerative processes that can determine not only the adaptation mechanisms to the factors of the external environment, but also possible irreversible alterations - the essence of one of the sides of the organism aging.

The purpose of this work was to investigate the features of adaptive growth, i.e. the state of regenerative processes in the liver without additional induction under the influence of cooling and in the highland conditions. The choice for liver research is dictated by the organ's important role in ensuring the organism resistance involved in any effects on the organism, as well as the peculiarities of regenerative processes — low proliferative activity, pronounced cell polyploidy, intensive regenerative response to damage.

\footnotetext{
* Corresponding author: sv9126000900@yandex.ru
} 


\section{Materials and methods}

Experiments were performed on male Wistar line rats with a mass of 150-250 g., as well as on male CBA mice of 19-22 g, contained in conditions of laboratory vivarium on a standard diet. All studies were carried out in accordance with the requirements of the European Convention for the Protection of Experimental Animals 86/609EEC. Cold exposure was made in a temperature chamber with positive-pressure ventilation with moisture and carbon acid absorber at $0^{\circ} \mathrm{C}$ for 23 hours a day with a break for feeding and care in cells with a small amount of litter, 3 animals per cell. We observed animal behavior, appearance and performance, noted the amount of food eaten, controlled rectal temperature, weight. To study the influence of highlands conditions for rats of one litter and the same mass, they were studied in Bishkek (Kyrgyz Republic) $-760 \mathrm{~m}$ above sea level (control) and delivered to the Tuya-Ashu pass - $3200 \mathrm{~m}$ above sea level, where they were kept on a standard diet in the high altitude base vivarium of the Central Research Laboratory of Kyrgyz State Medical Academy. The animals were taken in the experiment after 3 and 30 days of staying "at altitude".

After decapitation, all parts of the liver were quickly extracted, their weight and \% of dry weight were determined; histological preparations were prepared and stained for the review study and morphometrics using an ocular measuring grid and in accordance with the generally accepted methods. The DNA amount in cells was determined cytofluorimetrically (LUMAM I-3) using Schiff's reagent separately in single- and binuclear hepatocytes, 100140 cells from each liver sample, building cells distribution sums histograms by the ploidy classes, taking the fluorescence of zoosperm as a measure of chromosomes haploid set. Autoradiographic method using ${ }^{5-m e t h y l-3} \mathrm{H}$-thymidine, which was administered intraperitoneally 1.5 hours before slaughtering in a dose of $1 \mu \mathrm{Ci}$ per $1 \mathrm{~g}$ of weight (specific activity $890 \mathrm{Tbq} / \mathrm{mol}$ ), determined hepatocytes proliferative activity. Separation and purification of nucleic acids was conducted on the basis of G. Schmidt, S.J. Thannhauser (1945) method. The number of nucleic acids was determined spectrophotometrically. The DNA hydrolysate radioactivity was measured on a scintillation meter. Inclusion intensity of ${ }^{3} \mathrm{~N}$-thymidine was expressed in becquerels per $1 \mathrm{mg}$ of DNA.

Statistical data analysis was carried out using Microsoft Office Excel software. The distribution normality and variance homogeneity was evaluated according to Shapiro-Wilk. Calculated averages, average errors, standard deviation were calculated. The differences reliability between groups was assessed using Student's t-criterion or Mann-Whitney Ucriterion. The $\mathrm{chi}^{2}$ criterion was used to identify the distribution difference. The differences were considered credible at $\mathrm{p}<0.05$.

\section{Results and discussion}

Cold exposure after 3 days caused an increase in liver weight by $15.1 \%(\mathrm{p}<0.05)$. Liver index (mass per $100 \mathrm{~g}$ weight) after 3 days $-2.78 \pm 0.09$, which was $10.8 \%(\mathrm{p}<0.05)$ higher than in control animals $(2.51 \pm 0.06)$. It remained like this by the 7 th day of exposure still being increased by the 14 th day $(2.71 \pm 0.06,+8.0 \% \mathrm{p}<0.05)$. The increase in organ mass was not associated with the change in the tissue fluid amount - the percentage of dry matter in the liver did not decrease and even slightly increased by the 3 rd day $(+2.9 \%$ $\mathrm{p}<0.05)$ and by the 7 th day $(+5.0 \% \mathrm{p}<0.05)$. The histological study did not note significant changes. However, there was a noticeable change in the ratio of hepatocytes of different ploidy (table1) in the liver. Intermediate cell share increased classes ("synthesizing") in all studied time and most pronounced on the 7 th day of exposure. 
Table 1. Change of hepatocyte distribution by ploidy classes with cold introduction on rats, $\%$.

\begin{tabular}{|c|c|c|c|c|}
\hline \multirow{2}{*}{$\begin{array}{l}\text { Class } \\
\text { cells }\end{array}$} & \multirow{2}{*}{$\begin{array}{l}\text { Control } \\
\qquad(\mathrm{n}=7)\end{array}$} & \multicolumn{2}{|c|}{ Exposure time, } & days \\
\hline & & $3(n=7)$ & $7(n=8)$ & $14(\mathrm{n}=7)$ \\
\hline $2 \mathrm{C}$ & 1.9 & $6.4 *$ & $9.5 *$ & $7.8 *$ \\
\hline $2 \times 2 C$ & 2.0 & $1.2 *$ & 3.4 & 1.1 \\
\hline $4 \mathrm{C}$ & 20.4 & 21.0 & $29.8 *$ & $26.5 *$ \\
\hline $2 \times 4 C$ & 6.7 & $3.8 *$ & $3.3 *$ & $3.1 *$ \\
\hline $8 \mathrm{C}$ & 45.5 & $52.0 *$ & $36.3 *$ & $40.8 *$ \\
\hline $2 \times 8 C$ & 7.0 & $2.9 *$ & 4.9 & $3.4 *$ \\
\hline$>8 \mathrm{C}$ & 13.7 & $7.8 *$ & $3.9 *$ & 12.1 \\
\hline $2 x>8 C$ & 1.3 & 0.5 & $0.3 *$ & 2.1 \\
\hline $\begin{array}{l}\text { "Synthesizing" } \\
\text { cells }\end{array}$ & 1.6 & $4.4 *$ & $8.6 *$ & $3.1 *$ \\
\hline $\begin{array}{l}\text { Binucleate } \\
\text { cells }\end{array}$ & 16.9 & $8.8 *$ & $12.7 *$ & $9.7 *$ \\
\hline Average ploidy, C & 8.982 & 7.690 & 6.772 & 8.178 \\
\hline
\end{tabular}

Note: C-equivalent of one set of chromosomes; "Synthesizing" - cells of intermediate classes (2C-4C, $4 \mathrm{C}-8 \mathrm{C}$ and also binuclear); mean ploidy was considered without taking "synthesizing" into account; *- reliable differences $(\mathrm{p}<0.05)$ using the $\mathrm{chi}^{2}$ criterion $(800-1000$ cell fluorescence was measured in each group).

The number of binuclear cells decreased, especially after 3 days and mainly due to biconuclear polyploid cells $(2 \times 4 \mathrm{C}$ or more). The proportion of low ploidicity cells diploid (2C) and tetraploid (4C) was significantly increased. The calculated mean hepatocyte ploidy decreased. After 14 days of rats' cold exposure, the detected shifts decreased; there was a tendency to restore cellular composition, but the average ploidy did not reach the control level. The morphometry of liver cuts completely confirmed the dynamics of binuclear hepatocytes number in cold exposure. The change in the cells ratio of different classes was not associated with the elimination of certain hepatocytes as the index of liver alteration remained constant in all the time studied according to morphometry. The reason for the identified changes was the activation of proliferative processes in the tissue - initiation of DNA synthesis in cells, their division and further cell transition to the subsequent ploidy class or return to the initial class.

In general, a similar pattern was observed in the liver of male CBA mice under the same exposure regimes (Table 2). After 3 days, the number of cells with less ploidy $(2 \mathrm{C}, 2 \times 2 \mathrm{C}$, 4C) increased and the proportion of high-ploid hepatocytes decreased accordingly. Percentage of binuclear cells and average ploidy

Table 2. Effect of cold impact on the hepatocytes proportion of different ploidy in CBA mice, $\%$.

\begin{tabular}{|l|c|c|}
\hline \multirow{2}{*}{$\begin{array}{l}\text { Class } \\
\text { cells }\end{array}$} & \multicolumn{2}{|c|}{ Duration, days } \\
\cline { 2 - 3 } $2 \mathrm{C}$ & $3(\mathrm{n}=12)$ & $14(\mathrm{n}=12)$ \\
\hline $2 \times 2 \mathrm{C}$ & $+40.9^{*}$ & -20.5 \\
\hline $4 \mathrm{C}$ & $+124.1^{*}$ & $-55.9 *$ \\
\hline $2 \times 4 \mathrm{C}$ & $+13.2^{*}$ & +13.6 \\
\hline $8 \mathrm{C}$ & $-25.0^{*}$ & +5.9 \\
\hline $2 \times 8 \mathrm{C}$ & $-47.7^{*}$ & +4.4 \\
\hline$>8 \mathrm{C}$ & $-73.6^{*}$ & +35.0 \\
\hline $2 \times>8 \mathrm{C}$ & +1.5 & +16.4 \\
\hline Binucleate cells & - & $+166.4 *$ \\
\hline Average ploidy, C & $-20.5 *$ & +3.1 \\
\hline
\end{tabular}


Note: C-equivalent of one set of chromosomes; *- reliable differences $(\mathrm{p}<0.05)$ using chi $^{2}$ criterion (1000-1200 dimensions in each group).

decreases. After 14 days of cold exposure, the hepatocytes distribution by ploidy classes had little differences from control and the average ploidy was slightly increased. Dynamics in the hepatocyte population under these conditions was due to proliferative processes activation, which was evidenced by the measuring results of $3 \mathrm{~N}$-thymidine intensity inclusion in the liver DNA of CBA mice. After 3 days, only the trend of increase of this indicator $(+19.1 \% \mathrm{p}>0.05)$ was found, while after 14 days it was more than 2 times higher than the control level $(+119.6 \% \mathrm{p}<0.05)$. The change in DNA content in $1 \mathrm{~g}$ of liver was also of interest - it increased after 3 days by $19.7 \%(\mathrm{p}<0.05)$ and decreased after 14 days $(-32.2 \% \mathrm{p}<0.05)$. If this indicator is considered as a reflection of the ratio of the cellular structures number per unit of the genome, the reduction of DNA per $g$ of the liver may indicate the development of hepatocyte hypertrophy in these conditions.

The dynamics of the adaptive growth processes reaction in the liver of rats and mice differed slightly, however directionally similar shifts suggested a pattern of the changes identified. Low-temperature exposure causes activation of adaptive growth processes in the liver, in particular proliferation activation, reversible reduction of hepatocyte ploidy, as well as intracellular regeneration stimulation (hypertrophy) after some oppression in early terms of exposure.

The influence of highlands conditions on the adaptive growth processes in the liver of rats was investigated during the most dramatic deviations of physiological and metabolic parameters (3 days) and the period of sustainable adaptation formation (30 days). In the early period, there was a significant increase in the share of diploid cells $(+66.7 \% \mathrm{p}<0.05)$ and cells with the amount of DNA corresponding to the gap between classes $2 \mathrm{C}$ and $4 \mathrm{C}$. The number of tetraploid $4 \mathrm{C}(-24.6 \% \mathrm{p}<0.05)$, octoploid $8 \mathrm{C}(-76.7 \% \mathrm{p}<0.05)$ and intermediate $4 \mathrm{C}-8 \mathrm{C}$ cells (Table 3 ) decreased.

Table 3. Change in hepatocytes distribution by ploidy classes in highlands conditions, $\%$

\begin{tabular}{|l|c|c|c|}
\hline \multirow{2}{*}{$\begin{array}{l}\text { Class } \\
\text { cells }\end{array}$} & $\begin{array}{c}\text { Control } \\
(\mathrm{n}=8)\end{array}$ & 3 days $(\mathrm{n}=8)$ & 30 days $(\mathrm{n}=8)$ \\
\cline { 3 - 4 } $2 \mathrm{C}$ & 9.9 & $16.5^{*}$ & $16.2^{*}$ \\
\hline $2 \mathrm{C}-4 \mathrm{C}$ & - & $23.9^{*}$ & $12.1^{*}$ \\
\hline $4 \mathrm{C}$ & 74.8 & $56.4^{*}$ & $59.6^{*}$ \\
\hline $4 \mathrm{C}-8 \mathrm{C}$ & 3.1 & - & $6.5^{*}$ \\
\hline $8 \mathrm{C}$ & 11.6 & $2.7^{*}$ & $4.8^{*}$ \\
\hline Average ploidy, C & 4.299 & $3.514^{*}$ & 3.840 \\
\hline
\end{tabular}

The selective proliferation induction of diploid cells is remarkable, which is consistent with the data of the literature [7-9]. However, the growth of synthesizing cells was so large that it can be assumed that in parallel with the intensification of cell entry into the S-phase, DNA synthesis is somewhat oppressed, and cells were delayed in this intermediate class.

Simultaneously, the mitotic index (MI) increased by $228,6 \%(\mathrm{p}<0.05)$, the proportion of biconuclear cells decreased $21.4 \%(p<0.05)$ and the degenerative processes in the liver significantly increased, which was shown with an increase in the alteration index (IA) of $66.8 \%(\mathrm{p}<0.05)$ and histological pattern (table 4$)$.

For long stays at altitude, there are mostly the same histological changes in the liver as with acute exposure, yet less pronounced. Focal proliferation of stellate cells is noted. No mitoses were found in the preparations at the time of animal slaughter. The percentage of biconuclear cells increases by almost 2 times. Estimated mean liver ploidy is higher than that in three-day exposure, but remains lower than in control (-10.7\%). Apparently, a new 
stationary state of cell dynamics is formed, which is characterized by increased cell death $(\mathrm{IA}+43.0 \% \mathrm{p}<0.01)$ and its compensating activation of proliferative processes. In both 3 and 30 days of stay in the highlands, the nuclear cytoplasmic ratio is reduced, which is probably associated with the increasing development of cellular hypertrophy in the liver.

Table 4. Liver morphometric indicators change under conditions of highlands $M \pm m(n)$

\begin{tabular}{|l|c|c|c|}
\hline Indicator & Control & Exposure & time, \\
\cline { 3 - 4 } & & 3 days & 30 days \\
\hline Mitotic index, \%o & $0.7 \pm 0.4(4)$ & $2.3 \pm 0.2(4) *$ & $0(4)$ \\
\hline Binucleate cells, \%o & $29.5 \pm 3.8(10)$ & $23.2 \pm 2.3(10)$ & $57.8 \pm 4.6(4) *$ \\
\hline Alteration index, \%o & $71.0 \pm 5.1(10)$ & $118.4 \pm 4.8(10) *$ & $101.5 \pm 7.4(4) *$ \\
\hline Nucleoplasmic ratio, $10^{3}$ & $269 \pm 9(4)$ & $221 \pm 2(4) *$ & $210 \pm 3(4) *$ \\
\hline
\end{tabular}

In general, in the highlands conditions there was a state of adaptive liver growth quite similar to that in the action of cold: proliferation processes were stimulated, the average hepatocytes ploidy was slightly reduced, cell hypertrophy developed. Moreover, these phenomena were more pronounced in the early term of the extreme factor, further they were somewhat flattened - except for hypertrophy - but did not reach the initial level even after a month of factor in action.

Thus, under the conditions of extreme factors action on the body the liver regenerative processes are activated, which obviously has a compensatory and adaptive nature. The duration of the detected adaptive growth mechanisms rearrangement and possible changes in the nature of the reaction - the ratio of proliferation processes components, polyploidy, cellular hypertrophy - all of it requires further research. Notably, a more dynamic response from low-ploidic cells is observed, which aligns well with traditional notions of their earlier and intense response to regenerative stimulus [10-11]. The fact that in all the studied groups there was a decrease in the high ploid cells proportion in the liver, i.e. the phenomenon opposite to what normally develops as it grows older and organism ages is also of interest [12-15]. It appears that under unfavorable conditions some "rejuvenation" of the cell composition occurs in the tissue, which not only contributes to the current functional state of the organ, but also creates prerequisites for features and possible potential enhancement of the regenerative response to the damaging factor.

\section{References.}

1. L. Aruin, Liver, Structural Basis of Adaptation and Compensation of Violated Functions / Ed.D. C. Arkisov, 249-259 (Moscow: Medicine, 1987)

2. D. Sarkisov, General trends of compensatory and adaptive reactions and their structural support. Material basis of biological systems' reliability, Structural basis of adaptation and compensation of violated functions: manual of the AMS USSR, 36-57 (Moscow: Medicine, 1987)

3. S. Tsvirenko, Oxidative energy metabolism and state of regenerative processes in tissues, Essays of experimental pathophysiology, Collection of articles. Publishing house "SV-96" Yekaterinburg, 86-115 (1999)

4. N. Blinkova, S. Sazonov, S. Leontiev, Polyploidy of hepatocytes in liver regeneration for chronic hepatitis in patients from different age groups, 106 (Yunika, Ekaterinburg, 2017)

5. B. Yushkov, V. Klimin, Damage and regeneration, 132 (M.: Comment, 2017)

6. V. Bazarniy, I. Maklakova, D. Grebnev, V. Yusupova, E. Petrunina, Journal of ural medical academic science, 16 (3), 357-364 (2019) 
7. G. Stein., B. Kudryavtsev. J. Theor. Biol., 156, 349-363 (1992)

8. I. Uryvaeva, A. N. Izvestiya, Ser. biol., 6, 728-737 (2001)

9. G. Sakuta, B. N. Kudryavtsev, Cytology, 47 (5), 379-387 (2005)

10. G. Gentric, C. Desdouets, Am J Pathol, 184 (2), 322-331, (2013)

11. H. Gilgenkrantz, A. Collin de l'Hortet, Am J Pathol, 188 (6), 1316-1327 (2018) doi:10.1016/j.ajpath.2018.03.008

12. S. Celton-Morizu, C. Desdouets, Advances in Experimental Medicine and Biology, 676, 123-135, (2010) doi: 10.1007/978-1-4419-6199-0_8

13. S. A. Mao, J. M. Glorioso, S. L. Nyberg, Transl Res, 163 (4), 352-62 (2014) doi: 10.1016/j.trsl.2014.01.005

14. M. J. Wang, F. Chen, J.T.Y. Lau, Y. P. Cell Death Dis, 8 (5), e2805, (2017)

15.Z. Shu, S. Row, W. M. Deng, Endoreplication: The Good, the Bad, and the Ugly. Trends in Cell Biology, 28 (6), 465-474 (2018)

16. A. Abu Rmilah, W. Zhou, E. Nelson, L. Lin, B. Amiot, S. L. Nyberg, Wiley Interdiscip Rev Dev Biol, 8 (3), e340 (2019) doi: 10.1002/wdev.340 